\title{
AKIKET ARCUL CSAPOTT A VALÓSÁG - ROMA KÖZÖSSÉGEKET SEGÍTŐ HELYI PROGRAMOK ÉS AZOK VEZETŐI
}

Kállai Ernő Akiket arcul csapott a valóság címü kötetét kezünkbe véve az első benyomás, amely alapján biztosan kinyitja az olvasó a könyvet, az a sokatmondó és gondolatébresztő borítólap. A kötet borítóján egy szekeret toló embercsoport látható, a szekér elejét viszont egyetlen ember húzza. Ha ezt a képet értelmezni szeretnénk, akkor talán a legtöbb hazai, a cigánysággal és hátrányos helyzetű emberekkel foglalkozó kutatóban, szaktekintélyben, a civil szférában dolgozó személy gondolataiban felvillan egy, a cigányságot érintő probléma és az annak kezelését övező nehézségek. Ha ezen tovább szeretnénk menni, egy másik nézőpont mentén a cigányság kevésbé sikeres társadalmi integrációja és annak lehetséges okai, vagy a magyarországi cigányság sikeresebb társadalmi integrációját segítő, abban valamilyen formában elkötelezett segítő szakemberek arca és tevékenysége is eszünkbe juthat, akik elhivatottan, időt és energiát nem sajnálva próbálnak segíteni a hazai cigány közösségeknek, vagyis próbálják a ,szekerüket tolni”. Ezt a civil szférában dolgozó szakemberek nagy része együttmüködve, egymást segítve is igyekszik megtenni, ezt tekinthetjük a szekeret toló embercsoportnak, míg néhányan egy adott cigány közösség hátránykompenzálásában egyedül, gyakran segítség nélkül próbálnak részt venni, így ők ezt a bizonyos ,,szekeret egyedül húzzák", ők lehetnek ennek a szekérnek az elején, magányosan.

Így mindjárt a borítólap árulkodhat a tartalomról, amely nem más, mint néhány sikeresen és kevésbé sikeresen megvalósult helyi szinten kidolgozott, romákat segítő program vezetőivel készült beszélgetések gyűjteménye. Ezek a konkrét esettanulmányok nagyon érdekesek és jól használhatók az egyetemi oktatásban, de példát, ötletet, mankót adhatnak olyan, például helyi önkormányzatoknak, amelyek még küzdenek a településükön élö cigány lakosságot érintő nehézségekkel, de erőt meríthetnek a kötetböl azok is, akik néha megoldhatatlannak, javíthatatlannak találják munkájuk során a cigányság helyzetét. A kötet 2015 tavaszán egy, az MTA TK Kisebbségkutató Intézetében még akkoriban müködő Romakutatási Osztály által megvalósított rendhagyó kutatási és oktatási program eredményének tekinthető. A bevezetőt követően egy rövid elméleti tanulmány olvasható, amelyben elsősorban a legfontosabb, cigányságot érintő, országos kutatási eredmények mentén szemünk elé tárul a cigányság magyarországi története, de arról is olvashatunk, hogy az időnként megjelenő „,modernizációs-megélhetési válságok" hogyan segítették a cigányság marginalizált társadalmi helyzetének konzerválását. Ezt követi néhány kormányhatározat bemutatása, amelyek szemléltetik, hogy a rendszerváltás óta milyen beavatkozási kísérletek voltak a hazai cigányság 
felzárkóztatása kapcsán, és hogyan jelent meg innentől kezdve ebben folyamatosan a civil szféra. Majd néhány szempont alapján lényegében értékelésre kerül a tíz beszélgetőpartner legfontosabb gondolata, nehézségeik és motivációik, ezt a kötet meghatározó, talán legfontosabb részének is tekinthetjük. Végül a kötet második felében országosan elismert, de mégis különböző szakterület mentén (oktatás, tanodák, múvészet, egyházi intézmények vagy politika) és az ország különböző pontjain (Bátonyterenye, Ózd, Alsószentmárton vagy éppen Berettyóújfalu) élő más és más összetételủ és problémával küzdő roma közösséget felkaroló, másokat is inspiráló roma és nem roma személyiséggel készült félig strukturált mélyinterjúk olvashatók. A több szempont alapján való értékelésben olvasható, hogy az interjúalanyok nagy részét munkája során ,arcul csapta a valóság”, s ezt követően a legnagyobb hozzáértéssel és elhivatottsággal szánta el magát cselekvésre. A roma származású kezdeményezők első generációs értelmiségiek voltak, akik végigélték azokat az iskolai hátrányokat, amelyeket a mai cigány gyerekek is gyakran megtapasztalnak. Az ő sikerüket nagymértékben segítette, hogy az adott településen ismerték a személyüket, hiszen onnan emelkedtek ki, de azért volt olyan, akit munkájában inkább hátráltatott régi közössége. A nem romák esetében szintén értelmiségi emberek kerültek a mintába, akiknek az iskolai életútja sokkal sikeresebb volt, mint a roma származású interjúalanyoké, és akik közül sokan nem is készültek tudatosan arra, hogy a cigányokkal fognak foglalkozni. Náluk minden esetben valamilyen fordulópont, a társadalmi valóságra való ráeszmélés adta alapját a kezdeményezésük elindítására. Számukra sokkal nehezebb is volt elfogadtatni magukat a roma közösségükkel, ők találkoztak „,kívülállóságukkal” és azzal, hogy egy adott cigány közösség idegennek tartja őket. A nehézségeket az is táplálta, hogy többen közülük maguk is keveset tudtak a cigányokról. A cigány közösség bizalmának elnyerése hosszú folyamatnak tünt, amely több kudarcot is tartogatott számukra, míg a roma kezdeményezők „természetes emberek”, „közénk való” benyomást keltettek az adott közösségben. Minden interjúalany alapvetően a saját szűk érdeklődési és szakterületéhez kapcsolódó lehetőségek maximális kihasználásával akart segíteni, de rá kellett jönniük, hogy a roma közösségeket érintő gondok komplex, összetett problémát alkotnak, így más szervekkel is együttmüködésbe kezdtek. Az azonos szemléletmód mellett a lehetöségek és együttmüködések eredményeként más-más hatást és sikert értek el az interjúalanyok a saját civil közösségükben. A tíz interjúalany közül L. Ritók Nóra az egyik olyan nagy hatású civil szakember, akit „hatalmas erővel csapott arcul a valóság”, aki valóban, mint egy idegen, kívülálló személy saját tapasztalatai által értette meg és karolta fel a Berettyóújfalu és a környezö települések szegregátumaiban élő családok mindennapi problémáit. Kihasználva az alapítványi oktatási szféra adottságait egy saját alternatív pedagógiai módszert dolgozott ki, ami szociális, munkahelyteremtő elemet, egészségügyi elemet is tartalmaz, ezzel a komplex rendszerrel segíti a cigány/roma gyerekek, felnőttek életkörülményei- 
nek javulását, továbbá megtalálta a cigány közösség azon kulcsembereit, akik tudják segíteni az adott cigány közösség integrációjának elörelépését. A vele készült interjúban látatlanul is érződik az az elhivatottság, lendület, erő és kitartás, amellyel ő naponta dolgozik az őt érő vádak és negatív kritikák ellenére.

A tíz interjúalany munkája több közös siker- és kudarcelemet, kezdeményezésük fejlődése több hasonló fordulópontot tartalmaz, amelyek mentén összehasonlíthatóvá tudnak válni az elkészült interjúk. De ha az olvasó elmerül az interjúk részleteiben, rádöbben arra, hogy minden alany személyisége a saját valóságában magával ragadó és varázslatos, törekvéseik, mérhetetlen kitartásuk, segítő szándékuk valóban elismerést érdemlő. Olvasóként a kötetről Madách Imre $A z$ ember tragédiája címü drámájának elhíresült mondata jutott eszembe: „Mondottam, ember: küzdj és bízva bízzál!”, amellyel kívánom, hogy az interjúalanyok motivációja és elhivatottsága sose hagyjon alább, bármilyen nehéz körülmények között is kell dolgozniuk, ahogy a könyv szerzőjének is jó egészséget és további sok sikert kívánok oktatói és kutatói munkájához egyaránt.

(Kállai Ernö: Akiket arcul csapott a valóság. Roma közösségeket segítö helyi programok és azok vezetöi. Budapest: MTATKKI, 2019, 168 o. http://www.kallaierno.hu/data/files/kallai_akiket_arcul_csapott_valosag_dJwTB5.pdf)

Janó Evelin

Phd-hallgató

ELTE Társadalomtudományi Kar Szociológia Doktori Iskola 